ISSN : $2620-4665$ (print)

ISSN : $2620-4673$ (online)

Website : http://jurnal.untan.ac.id/index.php/JPLP2KM

\title{
OPTIMALISASI KESEHATAN SISWA MELALUI WIRAUSAHA JAJANAN SEHAT DAN HYGIENIS
}

\author{
Yuni Purwati ${ }^{1}$, Rico Saktiawan Jong Jaya ${ }^{2}$, Rishnu Kathulistiwi Magribi ${ }^{3}$ \\ 1 Universitas 'Aisyiyah Yogyakarta;2Universitas Alma Ata Yogyakarta \\ 3Universitas 'Aisyiyah Yogyakarta \\ email: ibudafa@gmail com
}

\begin{abstract}
The full activity in the school encourages students to better optimize food for snacks in the canteen. Snacks that are not covered, are less hygienic, use addictive substances such as preservatives, colorings, artificial sweeteners and dirty environment, there is no standard hand washing. Children can experience coughing, vomiting, digestive disorders, even growth and development disorders, chronic diseases, nutritional deficiencies and impaired learning achievement. Problems with students and canteen eating habits include lack of awareness about PHBS, school canteens lacking health requirements, canteen managers do not understand business management.

The solution is to do the PHBS training in Schools, to empower school residents to practice PHBS in schools. Activities with PHBS socialization, preparation of guidelines and procurement of PHBS facilities. The second activity is the Establishment of Healthy and Hygienic Canteens, to create a canteen that sells healthy and hygienic food. Activities include training for healthy \& hygienic canteens, the establishment of healthy and hygienic canteens, the preparation of food adaptations in the canteen and launching of healthy and hygienic canteens. The third activity is training on school canteen business management to provide entrepreneurial and marketing provisions for canteen managers. The output of the activity is the formation of PHBS culture in schools. The establishment of a healthy and hygienic canteen, the canteen manager applies effective snacks marketing management.
\end{abstract}

Keywords: PHBS, Healthy Canteen, Hygienic, Marketing

\section{PENDAHULUAN}

SMP Negeri 2 Kasihan Bantul berlokasi di Jetis Tamantirto Kasihan Bantul, terletak di Selatan Ring Road Perempatan Kasihan Bantul, tepatnya 300 meter ke Selatan. Letak sekolah yang jauh dari lalu lintas yang ramai, sehingga suasana yang diperoleh cukup tenang dan kondusif untuk proses belajar mengajar. Sekolah ini merupakan Sekolah Negeri yang telah terakreditasi A, terdiri dari 128 Siswa kelas VII, 132 siswa kelas VIII dan 134 siswa kelas IX, dengan jumlah total siswa adalah 394 siswa yang keseluruhan berada pada rentang usia 12-15 tahun. Kegiatan sekolah dilaksanakan pada pukul 07.00 - 13.30 WIB. Selain kegiatan pembelajaran, juga terdapat kegiatan ekstrakurikuler yang dilaksanakan pada hari Senin-Sabtu mulai pukul 14.00-15.30 WIB. Kegiatan ekstrakurikuler meliputi olahraga yang meliputi sepak bola, basket, volly, gate ball. 
Kegiatan seni meliputi karawitan, paduan suara dan seni baca qur'an dan pramuka yang diikuti seluruh siswa kelas VII-IX.

Aktifitas sekolah yang padat dan kegiatan sekolah yang dimulai pukul 07.00 WIB menyebabkan siswa tidak berkesempatan sarapan pagi dan hanya sekitar $20 \%$ siswa yang terbiasa membawa bekal ke sekolah. Hal ini mendorong anak lebih mengandalkan pangan jajanan di sekolah untuk memenuhi kebutuhan energinya selama berada di Sekolah. Makanan jajanan sudah menjadi bagian yang tidak terpisahkan dari kehidupan siswa di Sekolah. Konsumsi makanan jajanan terus meningkat dengan semakin padatnya kegiatan di sekolah, dimana kegiatan pembelajaran dilanjutkan dengan kegiatan ekstrakurikuler. Orangtua menjadi merasa lebih flexible dengan membawakan uang saku bagi anaknya ketika harus berada di sekolah dari pagi sampai menjelang sore hari. Namun, makanan jajanan yang disediakan di Sekolah yang ala kadarnya, tidak memperhatikan nilai gizi, hygienis dan syarat kesehatan, dan lebih mengutamakan harga murah serta mudah didapat, citarasa yang enak dan lebih cocok untuk selera sebagian besar anakanak.

Makanan jajanan yang dijajakan lebih banyak makanan instan yang mengandung bahanbahan adiktif seperti pengawet, pewarna, pemanis maupun perasa serta dengan kandungan nutrisi yang kurang baik untuk memenuhi kebutuhan anak. Makanan yang tidak sehat juga dapat berasal dari bahan makanan yang tercemar oleh karena pengolahan dan penyimpanan yang kurang hygienis atau proses penyajian dan pengemasan yang kurang baik. Dampak mengkonsumsi makanan jajanan yang tidak sehat ini tidak selalu dapat dirasakan secara langsung atau anak-anak hanya mengkonsumsi beberapa kali saja.

Bahan adiktif yang digunakan pada makanan dapat bereaksi dengan lapisan lendir saluran pencernaan dan saluran pernafasan. Di dalam tubuh dapat teroksidasi membentuk asam format terutama di hati dan sel darah merah. Dapat menimbulkan keracunan dalam tubuh, sakit perut, muntah-muntah, iritasi lambung, depresi susunan saraf, kegagalan peredaran darah maupun alergi (Wulandari, R; Ardiana, 2013).

Hasil pengujian sampel pangan jajanan anak sekolah, sebanyak 10.429 sampel dari seluruh Indonesia yang memenuhi syarat kesehatan sebesar $76,18 \%$ dan yang tidak memenuhi syarat kesehatan 23,8\%. Pangan Jajanan Anak Sekolah (PJAS) yang tidak memenuhi syarat kesehatan disebabkan oleh cemaran mikroba (67-79\%), bahan adiktif berlebihan (15-24\%) dan (5,9-12\%) tercemar bahan berbahaya (Rohima, 2016). Keberadaan kantin sekolah memegang peranan 
ISSN : $2620-4665$ (print)

ISSN : $2620-4673$ (online)

Website : http://jurnal.untan.ac.id/index.php/JPLP2KM

penting dalam mengembangkan budaya makan sehat, karena kantin sebagai penyedia utama makanan di sekolah, selain itu pembiasaan makan makanan sehat untuk usia anak sekolah dapat dimulai dari sekolah (Mitasari, 2017). Kantin mempunyai peranan penting dalam mendukung gizi siswa karena berdasarkan survei terhadap siswa bahwa 83,2 \% siswa tidak sarapan ketika berangkat sekolah dan hanya $20 \%$ siswa yang membawa bekal ke sekolah.

Gambaran kantin yang berada di sekolah terkesan menyediakan jenis makanan ala kadarnya, tidak hygienis dari segi makanan, sarana dan lingkungannya serta belum terkelola dengan baik. Jenis makanan berupa mie instan, es teh, bakso bakar, sosis bakar dan jenis-jenis makanan ringan instan kemasan. Penampilan kedua kantin sekolah tampak kurang terawat, tidak higienis, sampah makanan kurang terkelola dan tidak tersedia air mengalir untuk cuci tangan. Akibat dari kurang menariknya kantin sekolah tersebut, banyak dari siswa yang beralih jajan makanan di pinggir-pinggir jalan. Terlebih jajanan yang ditawarkanpun beraneka ragam. Pangan jajanan tersebut bentuknya menarik, rasanya enak dan harganya murah sehingga anak mempunyai minat yang tinggi untuk membelinya. Hal ini seringkali tidak disadari oleh siswa, orangtua maupun guru bahwa jajanan tersebut mengandung zat adiktif yang berbahaya bagi kesehatan anak. Anak dapat batuk, muntah, diare maupun gangguan pencernaan lainnya. Dampak lebih lanjut dapat terjadi gangguan pertumbuhan dan perkembangan, penyakit kronis, defisiensi gizi dan gangguan prestasi belajar (Rachmawati, Pertiwi, 2014).

Anak remaja adalah investasi bangsa, karena anak adalah generasi penerus bangsa. Kualitas anak di masa depan ditentukan oleh kualitas anak pada saat ini. Kebutuhan energi dan zat gizi di usia remaja ditunjukkan untuk deposisi jaringan tubuhnya. Total kebutuhan energi dan zat gizi remaja juga lebih tinggi dibandingkan dengan rentang usia sebelum dan sesudahnya. Gizi seimbang pada masa tersebut akan sangat menentukan kematangan mereka di masa depan. Masa remaja adalah saat terjadinya perubahan-perubahan cepat, sehingga asupan zat gizi remaja harus diperhatikan benar agar mereka dapat tumbuh optimal. Apalagi aktifitas fisik remaja pada umumnya lebih banyak, selain disibukkan dengan berbagai aktifitas di sekolah, umumnya mereka mulai menekuni berbagai kegiatan ekstrakurikuler, olahraga maupun hobi. Kegiatan ini tentunya akan menguras energi yang berujung pada keharusan menyesuaikan dengan asupan zat gizi seimbang (Sari, Sujana, \& Nugroho, 2017). 
Upaya meningkatkan sumber daya manusia harus dilakukan sejak dini, sistematis dan berkesinambungan. Tumbuh dan berkembangnya secara optimal pada anak usia sekolah tergantung pada asupan makanan dengan nilai gizi yang baik dan benar. Asupan gizi yang cukup serta keamanan pangan yang dikonsumsi sangat penting untuk diperhatikan termasuk Pangan Jajanan Anak Sekolah. Makanan jajanan menyumbang energi bagi anak sekolah 36\%, protein 29\% dan zat besi 52\% (BPOM, 2013). Dengan demikian merupakan tantangan bagi pengelola sekolah untuk memperhatikan bagaimana asupan gizi siswa sekolah tercukupi tanpa harus mengkonsumsi jajanan yang kurang sehat Selain itu juga merupakan tantangan bagi pengurus OSIS, khususnya di bidang seksi kreativitas, ketrampilan dan kewirausahaan untuk dapat meningkatkan unit usaha koperasi siswa melalui makanan jajanan sehat di sekolah.

Demikian juga hasil wawancara dengan Kepala Sekolah SMP Negeri 2 Kasihan Bantul menyatakan resah dengan kesehatan anak-anak didiknya. Siswa belajar di Sekolah selama 3 tahun, berangkat pagi tidak berkesempatan sarapan dan tidak membawa bekal.Siswa mengandalkan jajanan di sekolah untuk memenuhi kebutuhan energinya, sedangkan makanan jajanan di Sekolah jauh dari kondisi sehat dan hygienis. Kepala sekolah menyampaikan hal ini sebagai masalah yang harus dicari solusinya, sehingga para siswa dapat sehat, cukup gizi dan selalu berperilaku higienis di lingkungan sekolah. Sekolah berencana menindaklanjuti untuk mengembangkan kantin yang sesuai dengan standart dan budaya perilaku higienis di lingkungan sekolah.

Gambar berikut adalah kondii awal kantin:

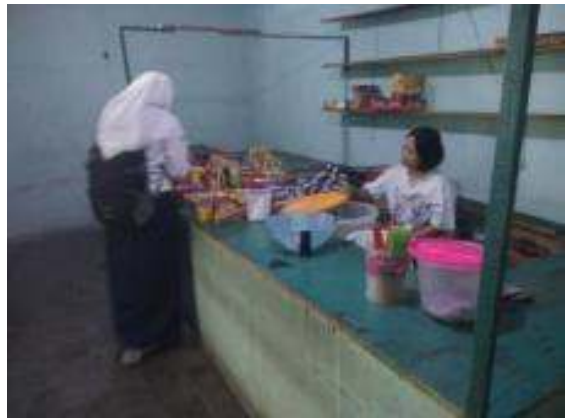

Gambar 1. Suasana Kantin 1

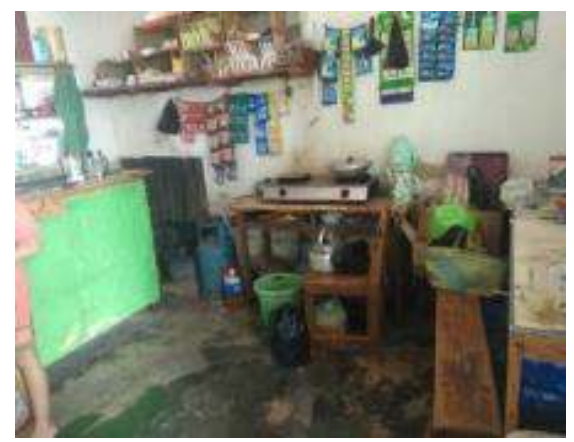

Gambar 2. Suasana Kantin 2 
ISSN : $2620-4665$ (print)

ISSN : $2620-4673$ (online)

Website : http://jurnal.untan.ac.id/index.php/JPLP2KM

\section{METODE PELAKSANAAN}

Mekanisme kerja dalam pelaksanaan Program Kemitraan Masyarakat ini dilaksanakan melalui tahapan sebagai berikut:

1. Observasi ke SMP Negeri 2 Kasihan Bantul untuk mengetahui kondisi kantin, jenis makanan jajanan yang dijajakan di sekolah, hygienitas lingkungan dan perilaku hidup bersih dan sehat masyarakat lingkungan sekolah seperti guru, siswa, pengelola kantin, satpam maupun tukang kebun sekolah.

2. Workshop tim pengabdi dengan pihak sekolah dalam perencanaan kegiatan pembentukan kantin sehat dan hygienis.

3. Pelaksanaan kegiatan utama:

a. Tahap 1: Pelatihan Perilaku Hidup Bersih dan Sehat di Sekolah, aktifitas yang dilakukan meliputi: sosialisasi PHBS, melengkapi sarana prasarana PHBS dan membuat poster PHBS sebagai bentuk kampanye PHBS.

b. Tahap 2: Pembentukan kantin sehat dan hygienis, aktifitas yang dilakukan meliputi: Pelatihan pengelolaan kantin sekolah, Identifikasi dan pengadaan syarat infrastruktur kantin, Penyusunan SOP adap makan siswa di kantin dan Launching kantin sehat di sekolah.

c. Tahap 3: Pemasaran Produk Jajanan Sehat di Sekolah. Aktifitas yang dilakukan meliputi: Pelatihan manajemen usaha dan strategi pemasaran jajanan sehat di sekolah, Pendampingan pembukuan usaha kantin dan Penerapan pemasaran pada launching kantin sehat.

4. Follow up keberlanjutan program penerapan PHBS dan wirausaha kantin sehat dan hygienis di sekolah.

\section{HASIL DAN PEMBAHASAN}

Pelaksanaan Pengabdian Masyarakat Program Kemitraan Masyarakat (PKM) ini dilaksanakan pada Bulan Maret 2019 dengan target selesai pada Desember 2019. Adapun hasil kegiatan yang telah dicapai samapai saat Bulan Agustus 2019 ini adalah sebagai berikut:

\section{Pelatihan Perilaku Hidup Bersih dan Sehat Bagi Siswa, Guru dan Pengelola Kantin} Kegiatan dilaksanakan pada 29 Mei 2019 Pukul 08.00-12.00 WIB di Ruang Laboratorium SMP Negeri 2 Kasihan Bantul dengan metode ceramah, diskusi, demonstrasi. Peserta 
yang mengikuti pelatihan ini sebanyak 40 peserta yang terdiri dari 30 siswa dan 10 guru dan pengelola kantin. Tahapan kegiatan yang dilakukan meliputi: memberikan materi tentang PHBS di Sekolah meliputi cuci tangan sebelum dan setelah makan, mengkonsumsi makanan sehat di kantin sekolah, olahraga yang teratur dan terukur, memberantas jentik nyamuk, tidak merokok di sekolah, menimbang berat badan dan tinggi badan setiap 6 bulan dan membuang sampah. di tempatnya. Demonstrasi tehnik mencuci tangan dengan sabun \& air mengalir 6 langkah. Redemonstrasi oleh siswa, guru dan pengelola kantin.

Hasil yang diperoleh dari kegiatan ini adalah:

a. Kemampuan peserta dalam praktek cuci tangan dengan air mengalir dan sabun dengan prinsip 6 langkah WHO. Setelah seluruh peserta mempraktekkan mencuci tangan dengan air mengalir dan sabun dipandu oleh pendamping, hasil yang didapatkan 30 peserta (100\%) dapat mempraktekkan dengan benar.

b. Menyiapkan sarana dan prasarana utama yang diperlukan untuk praktek PHBS di kantin sekolah, yaitu berupa perlengkapan cuci tangan dan tempat sampah tertutup.

c. Tersusunnya poster PHBS yang ditempel di dinding kantin sekolah dan UKS sebagai bentuk kampanye PHBS.

Berikut merupakan gambar pelaksanaan pelatihan dan pelaksanaan cuci tangan:

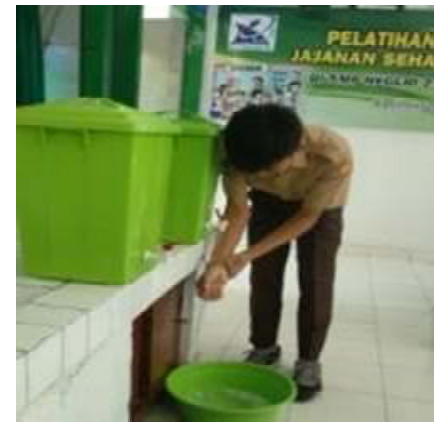

Gambar 3. Praktek mencuci tangan

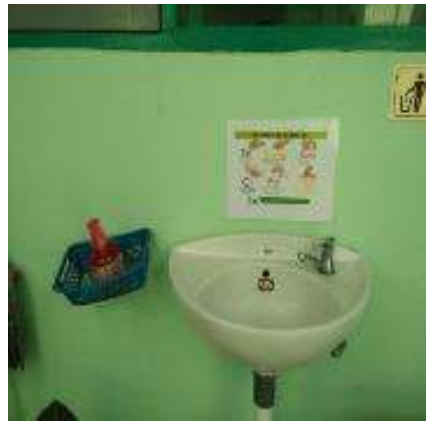

Gambar 4. Melengkapi sarana cuci tangan di kantin

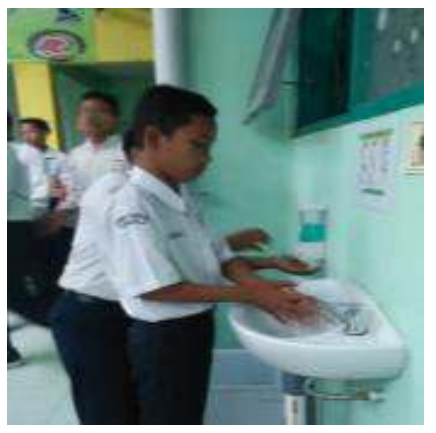

Gambar 5. Siswa mencuci tangan sebelum makan

Solusi pelaksanaan kegiatan ini didasari oleh penelitian (Irwandi, S., Ufattin, 2016) tentang peran sekolah dalam menumbuhkembangkan perilaku hidup sehat pada siswa sekolah. Program yang dilakukan melalui membuang sampah di tempat sampah, mencuci tangan sebelum dan setelah makan, makan dengan makanan yang sehat dan bersih yang 
ISSN : $2620-4665$ (print)

ISSN : $2620-4673$ (online)

Website : http://jurnal.untan.ac.id/index.php/JPLP2KM

disertai penempelan poster-poster PHBS. Pada siswa yang menunjukkan tindakan PHBS diberikan reward pujian dan yang terbukti tidak melakukan PHBS diberikan punishment berupa peringatan secara lisan dan sangsi pembelajaran yang sifatnya mendidik untuk menjaga kesehatan.

Pada perilaku hidup bersih dan sehat dalam pelatihan ini ditekankan pada mencuci tangan dengan sabun sebelum dan setelah makan dan membuang sampah pada tempatnya. Hal ini karena terkait erat dengan kebersihan tangan sangat penting sebelum dans etelah menyentuh makanan yang akan dimakan. Walaupun makanan telah disiapkan sehat dan hygienis, namun jika tangan yang digunakan untuk memegang makanan kotor, akan menyebabkan kontaminasi bakteri dari kotoran di tangan. Demikian halnya dengan sampah, anak-anak dibiasakan membuang sampah pada tempat yang tertutup sesuai dengan jenis sampahnya. Sampah yang berserakan menyebabkan lingkungan yang kotor dan disukai oleh lalat untuk berkembang biak. Jika menghinggapi makanan makan selain makanan kotor juga memicu perkembangbiakan bakteri penyebab penyakit. Hasil penelitian menunjukkan bahwa anak sekolah yang tidak melaksanakan cuci tangan sebelum makan, maka mudah terserang berbagai penyakit terutama yang berhubungan dengan perut seperti diare, kecacingan maupun thypus (Yetti, Citerawati, Perilaku, 2013.). Oleh karena itu walaupun cuci tangan memakai sabun sebelum makan suatu perilaku yang sepele, hal ini dapat berdampak serius pada gangguan organ pencernaan.

\section{Pembentukan kantin sehat dan hygienis}

Kegiatan dilaksanakan pada 29 Mei 2019 Pukul 13.00-16.00 WIB di Ruang Laboratorium SMP Negeri 2 Kasihan Bantul dengan metode ceramah, diskusi, demonstrasi. Peserta yang mengikuti pelatihan ini sebanyak 10 peserta yang terdiri dari guru dan pengelola kantin. Tahapan kegiatan meliputi:

a. Pengisian kuesioner Pengetahuan dan sikap pengelola kantin dalam persiapan kantin sehat dan hygienis

b. Materi Kegiatan tentang: a). kantin sehat yang memenuhi syarat kesehatan termasuk dalam persiapan infrastruktur terstandart; b). Pengelolaan dan penyajian menu di kantin yang memenuhi syarat sehat dan hygienis. 
c. Praktek demonstrasi menggunakan APD dan menyiapkan bahan makanan yang akan diolah.

d. Pengisian kuesioner Pengetahuan dan sikap pengelola kantin dalam persiapan kantin sehat dan hygienis

e. Materi Kegiatan tentang: a). kantin sehat yang memenuhi syarat kesehatan termasuk dalam persiapan infrastruktur terstandart; b). Pengelolaan dan penyajian menu di kantin yang memenuhi syarat sehat dan hygienis.

f. Praktek demonstrasi menggunakan APD dan menyiapkan bahan makanan yang akan diolah.

\section{Hasil kegiatan yang didapatkan meliputi:}

a. Hasil data pengetahuan dan sikap pengelola kantin sebelum dan setelah mengikuti pelatihan.

1) Pengetahuan dan sikap peserta sebelum diberikan pelatihan adab makan. Mayoritas peserta yang mempunyai pengetahun cukup, mempunyai sikap yang cukup baik pula, yaitu sejumlah 5 orang (50\%), dan yang mempunyai pengetahuan kurang dan mempunyai sikap kurang sebanyak 6 orang $(60 \%)$ dari 10 peserta $(100 \%)$.

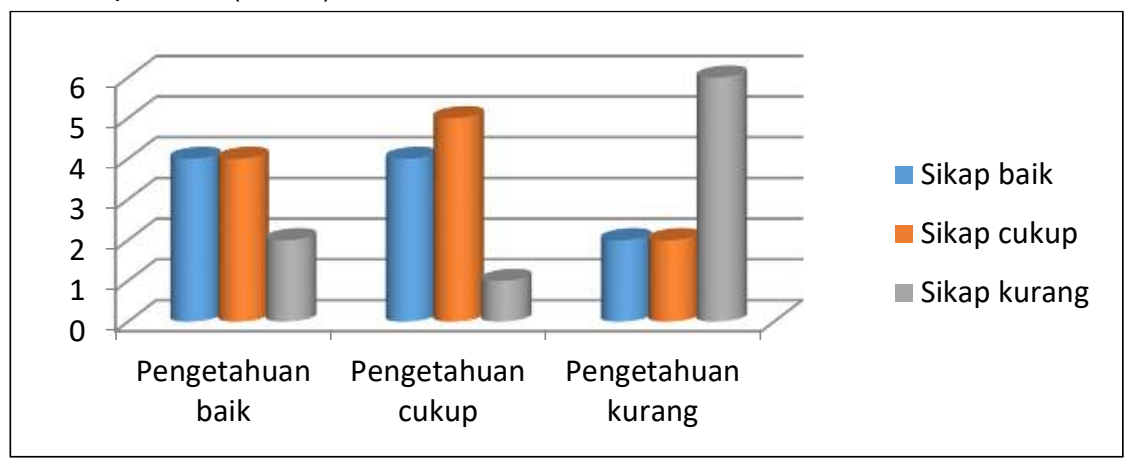

Diagram 1. Pengetahuan dan Sikap Peserta Sebelum diberikan Pelatihan adab makan

2) Pengetahuan dan sikap peserta setelah diberikan pelatihan adab makan. Mayoritas peserta yang mempunyai pengetahun baik, mempunyai sikap yang baik pula, yaitu sejumlah 7 orang $(70 \%)$ dari $10(100 \%)$ peserta. 
ISSN : $2620-4665$ (print)

ISSN : $2620-4673$ (online)

Website : http://jurnal.untan.ac.id/index.php/JPLP2KM

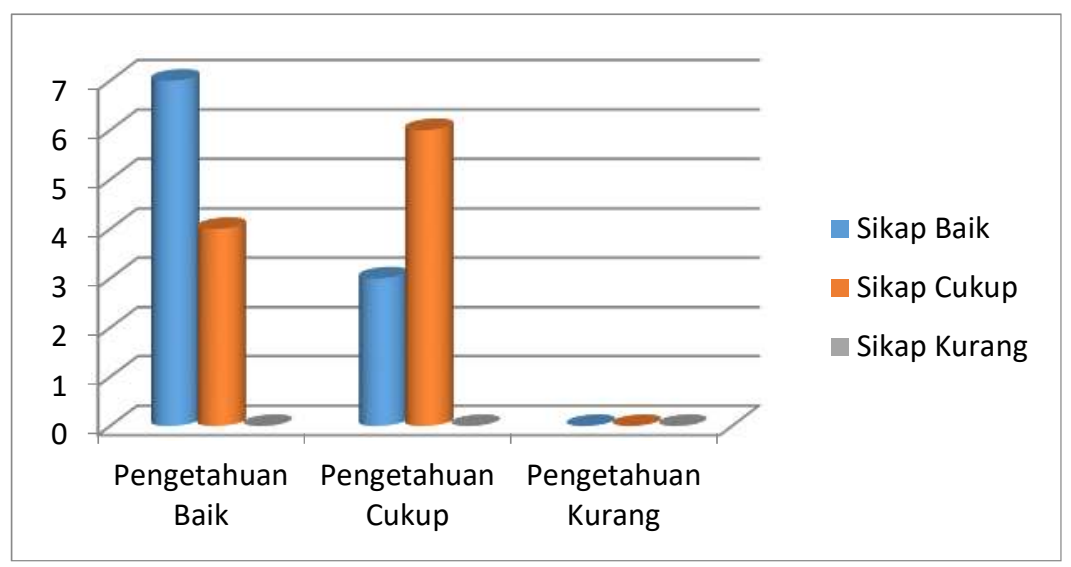

Diagram 2. Pengetahuan dan Sikap Peserta Setelah diberikan Pelatihan adab makan

b. Terbentuknya SOP adap makan

c. Terbentuknya kantin sehat dan hygienis dengan tenaga pengelola yang selalu menjaga kebersihat dan perlindungan diri menggunakan APD.

d. Struktur Organisasi Kantin sehat

Keberhasilan kegiatan ini sesuai dengan hasil penelitian Solusi yang ditawarkan ini didasari oleh hasil penelitian dari (Pratiwi, Sanubari, Christian, \& Noer, 2017) tentang analisis kantin sekolah dasar negeri Mangunsari berdasarkan kebijakan pemerintah. Hasil penelitian menyatakan bahwa dalam membangun kantin sehat sangat penting memperhatikan keamanan makanan dan minuman yang dijualnya, khususnya dalam aspek penerimaan makanan yang tidak mengandung MSG atau bahan pengawet, makanan yang tidak boleh mengandung pemanis berbahaya, pengemasannya tidak boleh menggunakan staples, tetapi harus diganti dengan selotip, bermutu, segar dan tidak busuk. Kantin sekolah harus memenuhi syarat-syarat kantin sekolah yang dikeluarkan oleh pedoman kementerian kesehatan RI tahun 2011 dan BPOM tahun 2012. Petugas kantin juga perlu menggunakan alat perlindungan diri sejak menyiapkan menu, memasak sampai dengan melayani pembeli, hal ini dilakukan untuk melindungi makanan supaya tidak terkontaminasi kotoran dari tubuh. Penjaga kantin yang melayani pembeli sebaiknya dalam kodisi sehat dan bersih, sehingga tidak menularkan penyakit dari tubuhnya ke makanan yang dijualnya. Apabila penjaja makanan dalam kondisi kurang sehat dan terpaksa harus 
menjajakan makanannya, alat perlindungan diri dan masker wajah mutlak harus digunakannya.

Pada pelatihan ini juga diajarkan tentang adab makan di kantin sekolah pada pengelola kantin dan perwakilan siswa OSIS. Adab makan sejak memesan amkanan, selama makan dan selesai makan. Hal ini karena menurut pengakuan dari peserta bahwa makan jajanan sekolah seringkali dilakukan dengan berdiri, sering lupa berdoa, mengambil makanan menggunakan tangan langsung, padahal telah disiapkan alat untuk mengambil makanan. Pada kegiatan ini sebelum dan setelah diberikan pelatihan adab makan, terdapat perubahan hasil yang menunjukkan bahwa pengetahuan dan sikap peserta untuk melaksanakan adap makan sebelum makan, selama makan dans etelah makan lebih baik.Perubahan sesuai dengan hasil riset (Noviyani, 2013) bahwa perubahan pengetahuan dan sikap menuju lebih baik dapat diperoleh dari kesan di dalam pikiran manusia akibat dari penggunaan panca indera. Pratiwi, Sanubari, Christian, \& Noer, (2017) menyampaikan bahwa sikap dan tingkahlaku yang bergerak menuju lebih baik terjadi karena rangsangan yang didapat terus menerus dan hasil dari melajar terus menerus yang dilaksanakan seseorang. Berikut gambar-gambar pembentukan kantin sehat:

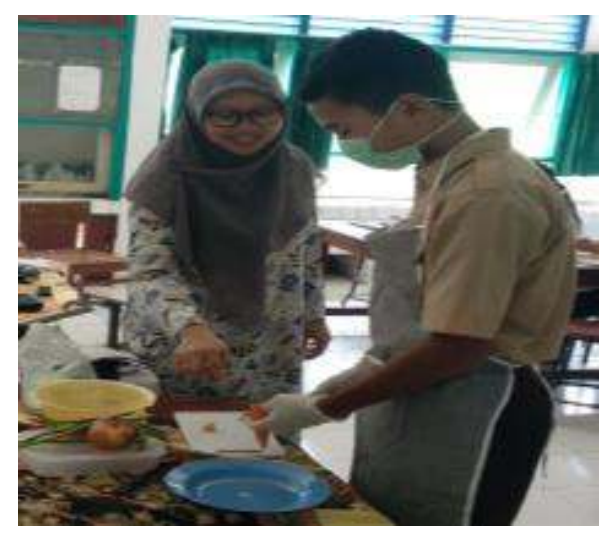

Gambar 6. Praktik mengelola bahan makanan, petugas menggunakan APD

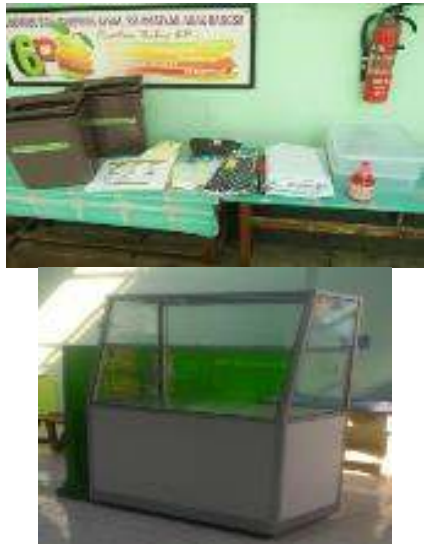

Gambar 7. Persiapan Sarana Prasarana kantin 
ISSN : $2620-4665$ (print)

ISSN : $2620-4673$ (online)

Website : http://jurnal.untan.ac.id/index.php/JPLP2KM

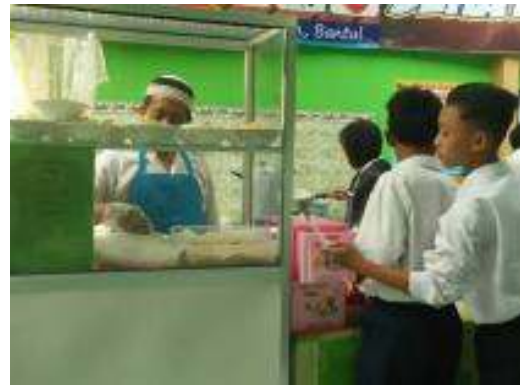

Gambar 8. Penjual kantin sedang melayani pembeli (siswa)

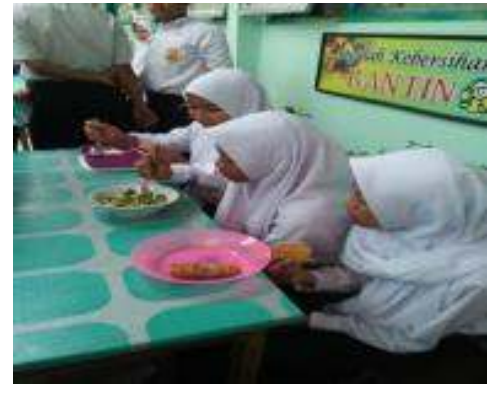

Gambar 9. Siswa jajan sedang makan di kantin.

\section{Pemasaran Produk Jajanan Sehat di Sekolah}

Kegiatan dilaksanakan pada 29 Mei 2019 Pukul 15.00-16.00 WIB di Ruang Laboratorium SMP Negeri 2 Kasihan Bantul dengan metode ceramah, diskusi, demonstrasi. Peserta yang mengikuti pelatihan ini sebanyak 10 peserta yang terdiri dari guru dan pengelola kantin. Tahapan kegiatan yang dilakukan meliputi: penyampaian materi pemasaran produk jajanan sehat di sekolah dan praktek penghitungan keuntungan hasil pemasaran produk.

Hasil yang diperoleh dari kegiatan ini adalah terdapatnya media promosi kantin sehat berupa spanduk keberadaan kantin sehat dan hygienis beserta daftar menunya. Produk yang dijual di kantin habis 100\% dengan jajanan yang dijual berupa produk yang tidak tahan lama, yaitu hasil memasak langsung. Hal ini sesuai dengan hasil penelitian dari (Diniaty, 2014) tentang perancangan strategi pemasaran produk. Pada penelitian ini menyatakan bahwa strategi pemasaran dapat menentukan minat beli pelanggan. Hal yang paling penting adalah selalu memunculkan ide kreatif dan mengikuti permintaan konsumen, menciptakan inovasi, menjaga kualitas produk. Pada barang yang kurang laku, dapat diturunkan harganya dengan menurunkan keuntungan tetapi penjual tidak akan rugi akbat penurunan harga produk. Strategi ini dapat meningkatkan kepuasan dan omzet penjualan produk.

Pada pelatihan pemasaran produk jajanan sehat di sekolah, dilaksanakan dengan metode membuat kreasi jajanan yang bersih dan menarik, namun tidak menggunakan bahan-bahan berbahaya. Penampilan petugas kantin dan kebersihan lingkungan juga merupakan promosi yang menarik pembeli. Peserta juga diajarkan tehnik pembukuan antara jumlah pengeluaran untuk belanja, pengeluaran tenaga, nilai jual dan menghitung 
laba penjualan. Membuat spanduk yang menarik yang menginformasikan keberadaan kantin juga merupakan sarana promosi yang merupakan daya tarik pembeli. Dengan spanduk ini, seluruh warga sekolah menjadi mengetahui jenis jajanan yang dijual di kantin sekolah dan variasinya. Hal ini meningkatkan animo dari anak - anak sekolah, jika membutuhkan jajanan telah tersedia di kantin sekolah dengan jenis makanan yang tidak kalah menarik dengan yang dijajakan diluar sekolah dan tetap memperhatikan syarat kesehatan(Hartono, 2016).

Sebagai dukungan promosi yang terus menerus, tim pengabdi memberikan pendampingan dalam pembentukan dan penataan kantin serta promosi. Konsep jajanan kantin dengan petugas mengambil jenis makanan sendiri, sehingga makanan harus sering dibuka, untuk jajanan penganan dengan ditempatkan pada sea/ware yang besar lengkap dengan tutupnya, sehingga dapat segera ditutup kembali apabila tidak ada pembeli dan makanan akan tetap bersih, tidak tercemar lingkungan. Pada jajanan makanan yang mengenyangkan seperti soto, bakso, nasi kuning dan nasi kucing ditempatkan pada etalase tertutup, hal ini juga untuk menjaga kebersihan makanan dan mencegah kontaminasi makanan karena lingkungannya. Di kantin juga disediakan alat cuci tangan dengan air mengalir, lengkap dengan sabun dan lap tangan yang dilengkapi dengan petunjuk cuci tangan. Sebagai upaya tetap menjaga kebersihan lingkungan, disiapkan tempat sampah tertutup, sehingga para siswa yang makan di kantin sekolah dapat segera membuang sampah pada tempat yang disediakan sesuai dengan jenis sampahnya.

Di kantin juga ditempelkan poster PHBS untuk selalu mengingatkan warga sekolah yang berkunjung di kantin, selalu dapat melaksanakan PHBS. Selain itu, juga disiapkan SOP adab makan, sehingga siswa dapat selalu ingat untuk selalu mempraktekkan adap makan di kantin sekolah. Upaya ini dilakukan seluruh pengunjung kantin sekolah puas dengan jajan di kantin sekolah, pengelola kantin tetap dapat menikmati keuntungan dari hasil usahanya, warga sekolah khususnya siswa dapat optimal kesehatannya karena mengkonsumsi jajanan sehat, hygienis dan bergizi. Dampak berikutnya, orangtuaakan lebih tenang, walaupun belum sempat membekali anaknya dengan bekal makanan atau sarapan dari rumah, di sekolahpun telah disediakan makanan yang bersih, sehat dan layak konsumsi untuk memenuhi kebutuhan energi anak-anaknya selama di sekolah. 
ISSN : $2620-4665$ (print)

ISSN : $2620-4673$ (online)

Website : http://jurnal.untan.ac.id/index.php/JPLP2KM

\section{KESIMPULAN}

Pada kegiatan pengabdian masyarakat di SMP Negeri 2 Kasihan Bantul dengan program optimalisasi kesehatan siswa melalui wirausaha jajanan sehat dan hygienis telah dilaksanakan pelatihan dan pendampingan pembentukan kanitin sehat, pengolahan jajanan sehat dan penyajian jajanan sehat. Kegiatan ini melibatkan kepala sekolah, pengelola kantin, penanggung jawab kantin, guru dan siswa serta tim pengabdi. Kegiatan ini juga meliputi penerapan SOP adap makan di kantin, perilaku hidup bersih dan sehat di sekolah. Rangkaian kegiatan ini berdampak pada pengetahuan pada pengelola kantin, kepala sekolah dan penanggung jawab kantin, sehingga ditindak lanjuti dalam pembentukan kantin yang sehat dan hygienis dengan memberdayakan infra struktur yang ada. Bagi siswa pengetahuan tentang perilaku hidup bersih dan sehat dan adab makan di kantin, diterapkan dalam perilaku sehari-hari untuk dapat menjaga kesehatannya.

\section{REKOMENDASI}

Pada pengelolaan kantin sehat dan hygienis diperlukan adanya kerjasama dengan instansi kesehatan untuk menjamin kualitas pangan jajanan anak sekolah di kantin untuk menjamin kualitas pangan yang sehat, aman dan bergizi.

\section{UCAPAN TERIMAKASIH}

Ucapan terimakasih disampaikan kepada:

1. Kepala Sekolah SMP Negeri I Kasihan Bantul beserta jajaran dan pengelola kantin, yang telah memberikan data, mengijinkan dan mendukung kesuksesan dalam pelaksanaan pengabdian masyarakat ini serta pelaksanaan tindaklanjut berikutnya.

2. Rektor Universitas Aisyiyah Yogyakarta yang telah memberi ljin dan mendukung dalam pelaksanaan Pengabdian Masyarakat ini.

3. Direktorat Riset dan Pengabdian Masyarakat Direktorat Jenderal Penguatan Riset dan Pengembangan Kementerian Riset, Teknologi dan Pendidikan Tinggi yang mendanai pelaksanaan pengabdian masyarakat ini, dengan perjanjian Surat Keputusan Rektor UNISA No: 61/LPPM/UNISA/IV/2019.. 


\section{DAFTAR PUSTAKA}

BPOM, (2013). Pedoman Pangan Jajanan Anak Sekolah Untuk Pencapaian Gizi Seimbang (orangtua dan pengelola kantin). Direktorat Standarisasi Produk Pangan Deputi Bidang Pengawasan Keamanan Pangan dan Berbahaya, BPOM RI.

Diniaty, (2014). Perancangan Strategi Pemasaran Pada Produk Anyaman Pandan. Jurnal Sains, Teknologi \& Industri, Vol 11 No.2:175-184.

Hartono, (2016). Hubungan Pengetahuan Guru Dan Pengelola Kantin tentang Gizi (BTP) Terhadap Pengguna BTP Beresiko Pada Makanan Anak di Sukoharjo. Jurnal Terpadu IImu Kesehatan, Vol.5 No. 2, hal. 110-273.

Irwandi, S., Ufattin, (2016). Peran Sekolah Menumbuhkembangkan Perilaku Hidup Sehat Pada Siswa Sekolah Dasar. Jurnal Pendidikan, Teori, Penelitian \& Pengembangan, Vol.1 No.3, 492-498.

Rachmawati, Pertiwi, (2014).Workshop Penyusunan Program dan Penyiapan Menu Makanan Tambahan Anak Sekolah Bagi Guru SD Inklusif DIY. Universitas Negeri Yogyakarta.

Rohima, (2016).Kajian Program Makanan Tambahan Untuk Anak Sekolah (PMT-AS) di Bandung. Infomatek, vol.18, no.1.

Sari, Sujana, \& Nugroho, (2017). Hubungan Status Gizi dengan Kejadian Anemia Pada Remaja Putri di SMK Muhammadiyah I Moyudan Sleman Yogyakarta. Naskah Publikasi Universitas Aisyiyah Yogyakarta. http://lib.unisayogya.ac.id/

Pratiwi, Sanubari, Christian, \& Noer, (2017) Analisis Kantin Sekolah Dasar Negeri Mangunsari 03 Salatiga Berdasarkan kebijakan Pemerintah. Kesmas: Jurnal Kesehatan Masyarakat, vol.11 No.2, 175-180.

Noviyani, (2013). Efek Pemberian Makanan Tambahan Anak Sekolah Pada Peningkatan Prestasi Belajar. Naskah publikasi universitas Muhammadiyah Surakarta.

Wulandari, R; Ardiana, (2013). Hubungan antara perilaku Mencuci tangan dengan Insiden Diare pada Anak Usia Sekolah di Kabupaten Jember. Jurnal Terpadu ilmu Kesehatan. Vol:1, No: 188-192.

Yetti, Citerawati, Perilaku, 2013.). Pembentukan Perilaku.

http://adingpintar.wordpress.com/2012/03/19/25/ tanggal 8 Agustus 2018 